\title{
The Effects of the Global Financial Crisis on China's Financial Market and Macroeconomy
}

\author{
Linyue Li, ${ }^{1}$ Thomas D. Willett, ${ }^{1,2}$ and Nan Zhang ${ }^{1,3}$ \\ ${ }^{1}$ Claremont Institute for Economic Policy Studies, Claremont, CA 91711, USA \\ ${ }^{2}$ Claremont Graduate University and Claremont McKenna College, Claremont, CA 91711, USA \\ ${ }^{3}$ Milken Institute, Santa Monica, CA 90401, USA \\ Correspondence should be addressed to Thomas D. Willett, thomas.willett@cgu.edu \\ Received 21 November 2011; Accepted 11 December 2011 \\ Academic Editor: Richard C. K. Burdekin
}

Copyright (C) 2012 Linyue Li et al. This is an open access article distributed under the Creative Commons Attribution License, which permits unrestricted use, distribution, and reproduction in any medium, provided the original work is properly cited.

\begin{abstract}
This paper provides a brief review of the increasing importance of China in the world economy and discusses the spillover effects of the global financial crisis on China's financial markets and macroeconomy. It presents and critiques alternative ways of estimating these effects. Contrary to much popular discussion, China was hit fairly hard by the global recession generated by the financial crisis. It suffered a huge drop in exports, and these effects on the economy were only partially offset by China's huge stimulus program. While growth remained well above international averages, its drop was of the same order of magnitude as for the United States. The paper closes with a brief discussion of some of the major challenges facing China to rebalance its economy in order to sustain high growth.
\end{abstract}

\section{Introduction}

In the last two decades, China's economy has emerged as a major player in the world economy. China's high GDP growth has changed the distribution of economic activities across the world. It has passed Japan to become the second largest economy, and it is only a matter of time before it passes the United States. China's exports have lowered consumer prices across the globe, and its imports have begun to have a major impact on global commodity prices. China has become a major hub of intraindustry trade. From this point of view, China may become the engine of the world economy.

It is more important than ever to know how China responds to the global economy, especially the global financial crisis and ongoing concerns regarding US recession. This paper provides a brief review of China's economic position in the world economy, discusses the spillover effects of the global financial crisis on China's financial markets and the real economy, presents and critiques alternative ways of estimating these effects, and analyzes the reasons for the limited impact of the global crisis on China. One interesting result is that while China was not one of the countries hardest hit by the crisis, neither was it as insulated as many have assumed.
While its high growth rate during the crisis was the envy of most other countries, China's growth was substantially lowered by the crisis, suggesting that the decoupling of China's growth from the advanced countries may not be as great as many popular analyses have suggested. The paper also provides a discussion of the major challenges facing China for a sustainable growth.

\section{China's Position in the World Economy}

From 1978 to 2010, the share of China's GDP in the world economy increased from $1.7 \%$ to $9.5 \%$, when valued at market exchange rates [1]. The share of China's GDP in the world economy is even higher if purchasing power adjusted prices were applied. This is due to both the differences between the prices of traded and nontraded goods that lead to an understatement of the real incomes of most developing countries and an exchange rate that it is widely (although not universally) viewed as being substantially undervalued. The increasing weight of China and the other emerging countries in the world economy not only has helped contribute importantly to global growth but also has helped diversify 
the engines of global growth. This in turn over time should help contribute to greater stability in global growth.

Since the 1970s, the value of Chinese trade has approximately doubled every four to five years, gaining speed after the economic reforms launched in 1992. With this rapid growth, in 2010, China overtook Germany as the world's top exporter with exports worth about 1.5 trillion US dollars. By this time, China's share of world exports had risen to around 10\%, up from 3\% in 1999 [2], while the United States came in third behind Germany on the list [3]. Meanwhile, China's imports ranked third in the world at about 1.3 trillion US dollars in 2010. This rapid growth has transformed China from a negligible player in world trade to the world's leading exporter and a substantial importer [4].

China exports not only consumer goods but also electrical and other machinery, including data processing equipment, apparel, textiles, iron and steel, and optical and medical equipment, while its major imports include electrical and other machinery, oil and mineral fuels, optical and medical equipment, metal ores, plastics, and organic chemicals [5]. Since China serves as the most important assembly center for the world factory, its imports also include substantial quantities of parts and components that are subsequently incorporated into China's exports. (A recent study by Li [6] confirmed that intraindustry trade plays an important role in the transmission of business cycle synchronization, financial crisis, and spillover effects, by using both correlation approaches and dynamic factor models).

While China's exports have led to lower prices for consumers across the globe, this competition has also generated dislocations for many producers in other countries who in turn have been placing pressure on national governments to offer them protection against what they allege to be unfair competition. These pressures have been particularly strong in the United States and have been felt in many other countries as well.

In the US Congress, China's huge bilateral surplus with the United States has been a particular focus of attention. It is important to recognize, however, that in part because of China's important role as a center of intraindustry trade, this bilateral imbalance substantially overstates the amount of global disequilibrium that is being generated by China's super competitiveness. For example, China runs bilateral deficits with a number of Asian economies that provide inputs to its exporting firms. It should also be noted that a substantial promotion of China's exports are generated by multinational corporations, not just Chinese firms.

With China taking up more than $20 \%$ of world platinum and $17 \%$ of world palladium demand, news of the tightening policy from China had a swift downward effect on commodity prices and roiled world markets [7], while in countries such as the United States, most attention is paid to China's exports. However, China is also a major importer, especially of commodities. China's strong stimulus package during the global financial crisis resulting in strong import demand was an important prop for global commodities prices. The more recent concern about rising inflation has led to a substantial monetary tightening in China which has also had a major impact on commodity prices.
TABLE 1: China's annual GDP growth rates.

\begin{tabular}{lccccccc}
\hline Year & 2005 & 2006 & 2007 & 2008 & 2009 & 2010 & 2011 (estimated) \\
\hline China 11.30 & 12.70 & 14.20 & 9.60 & 9.22 & 10.33 & 9.47
\end{tabular}

Source: IMF World Economic Outlook.

TABLE 2: China's net FDI in \$ billions.

\begin{tabular}{lcccccc}
\hline Year & 2005 & 2006 & 2007 & 2008 & 2009 & 2010 \\
\hline China & 105.90 & 102.92 & 143.06 & 121.68 & 70.32 & 124.93 \\
\hline
\end{tabular}

Source: World Bank World Development Index.

\section{Spillover Effects of the Global Financial Crisis on China's Economy}

The subprime financial crisis in the United States unleashed a series of severe effects from the stock market collapsing, financial institutions failing, and economies pushed in recession. The crisis spread from real estate to other sectors of economy and across the globe leads to the global financial crisis (for discussion of the spread of the crisis, see the analysis and references in Willett et al. [8]). Although China was able to maintain relatively high economic growth, the negative effects from the global financial crisis on China were considerably stronger than is often realized. This misconception arose largely because China continued to have one of the highest rates of economic growth across the globe, recording $9.6 \%$ in 2008 and $9.2 \%$ in 2009 (Table 1). What is typically missed is that, while most countries would be delighted to have such growth, these rates reflected a substantial drop from the $14.2 \%$ growth in 2007 . This is discussed in more detail in Section 4. In terms of the falls in growth rate during the crisis period, China was hit hard as many of the advanced economies (see Willett et al. [9]).

The crisis spread through a number of channels. In the initial stages, financial channels were the most important. Financial institutions from a number of countries, especially in Europe, had invested heavily in securities linked to the US real estate market. These investors suffered huge losses. These investors generated a general flight to safety which led to large capital outflows from many emerging market economies that had few direct linkages with the US real estate market. China proved to be largely immune to these wealth and capital flow effects. FDI in China decreased during the beginning of financial crisis and rebounded to almost the precrisis level later on. As shown in Table 2, China's net FDI decreased to $\$ 121.68$ billion and $\$ 70.32$ billion in 2008 and 2009, dropping $15 \%$ and $42 \%$ year on year, respectively, and increased to $\$ 124.93$ billion in 2010 .

However, there was also a global financial impact that did not operate directly through capital flows. The crisis affected the economic outlook and risk attitudes across the globe and China was not immune. Before the crisis, extreme optimism had affected many markets across the globe and China's stock market was no exception. Like in many other countries, China had enjoyed a stock market boom, increasing fivefold between 2005 and 2007. Such rapid growth makes markets 
highly likely to suffer major reversals, and this is just what occurred when bad news hit.

Starting in October 2007, the stock market in China crashed, wiping out more than two-thirds of its market value [10]. A similar story applies to the real estate market. A bubble started to grow with China's booming economy, since most of the people believe that investing in property, such as real estate, is safer than putting money in the banks. The impacts of these developments on the Chinese economy were relatively small compared with the trade channel, however.

In its early stages, the magnitude of the crisis was substantially underestimated by most governments as well as private sector analysts. The adverse effects on the real economies were expected to be quite limited. Thus, it was believed that most emerging market economies would be little affected. This gave a bit boost to arguments that the behavior of emerging economy financial markets were decoupling from those of the advanced economies. However, as the crisis began to push the US and Europe into recession, the trade channel came to the fore. The falling demand in advanced economies had a huge impact on their demand for imports from each other and from emerging markets. With its past rapid growth in exports, China was especially exposed to falls in global demand for its exports.

In November 2008, China's export growth rate fell sharply to $-2.2 \%$ from $20 \%$ in October. As a whole, China's exports fell by about $17 \%$ in 2009 [2], before recovering to positive growth in 2010, as the advanced countries began to grow again (Figure 1). The rebounds of economic growth in advanced countries have been modest, and this has limited the size of the rebound in China's exports. Although it remains too early to say that China's export business has leveled off [11], development of the domestic market will help maintain China's sustainable economic growth over the long term.

\section{The Limited Impact of the Financial Crisis on China and the Decoupling View}

Although the global financial crisis and economic downturn reduced foreign demand for China's exports substantially for the first time in many years, China has kept its relatively high growth rate during the crisis period. In 2010, China's economy rebounded, with GDP growth of around 10\% outperforming all other major economies [5]. China's economy still has great potential despite the slight softening in 2011 that was noted earlier.

Due to its standout growth rate in the face of the global economic recession, China has set off a new round of discussions on the decoupling hypothesis. Careful analysis suggests, however, that while the rapid growth of economies such as Brazil, China, and India has substantially increased their influence on the global economies and especially on countries in their geographic regions, beliefs in a corresponding decline in the influence of the advanced economies were greatly overstated. The proper measure of the impacts of developments on a country's economic growth rate is how different the growth rate is from what it would otherwise have been. There is considerable scope for disagreements among

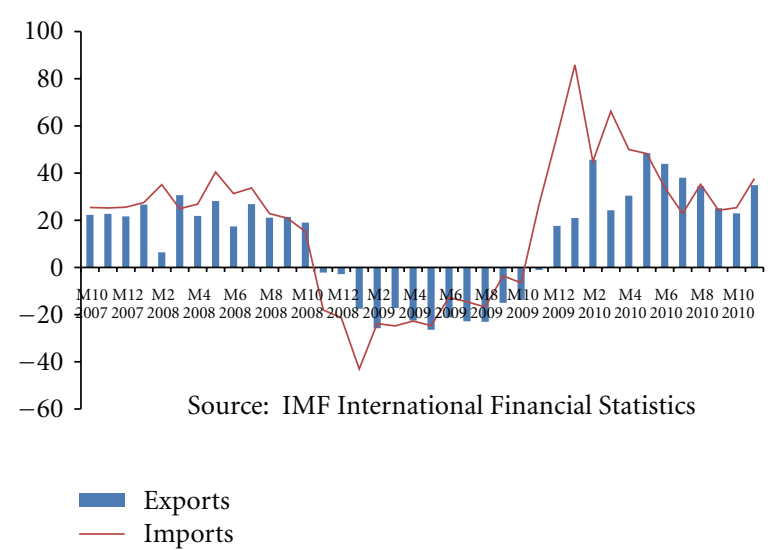

FIGURE 1: China's gross exports and imports growth.

TABLE 3: Deviations of GDP growth from the trend for China, India, and the US (linear trend from 2000 to 2006).

\begin{tabular}{cccc}
\hline & China & India & US \\
\hline 2006 & 0.3 & -0.2 & -0.2 \\
2007 & 1.2 & -1.9 & -0.7 \\
2008 & -3.4 & -5.2 & -2.5 \\
2009 & -4.4 & -7.5 & -5.7 \\
\hline
\end{tabular}

Source: Willett et al. [9].

exports about just what the counterfactual would have been, but we can get a ballpark idea by comparing the changes in growth rates from before to during the crisis. Willett et al. [9] have investigated GDP growth and the stock markets in the United States and other advanced and emerging market economies during the global financial crisis through 2009 and find that, while countries like China and India had been able to maintain high growth rates, their shortfalls of GDP growth below past trends have not been that much different than for the United States itself. For example, in 2008, the deviation from trend of China's growth is -3.4 percentage points, even greater in absolute terms than the United States decline of 2.5 percentage points (although proportionately still less of a hit). In 2009, the rankings of deviations are reversed (Table 3 ). For the two years combined, the growth short falls are almost identical, 7.8 for China and 8.2 for the United States. Of course, different methods of detrending will give somewhat different figures so little weight should be given to the exact numbers calculated, but the broad conclusion that the declines for China and the US were roughly similar and robust (again, see Willett et al. [9]). That the impact on growth in China was roughly the same as in the country of origin clearly shows that not only does China now have a major impact on the world economy but that the world economy can have a major impact on it. Economic interdependence is a two-way street.

This should not be surprising since China's exports make up roughly $40 \%$ of its GDP and China depends heavily on western demand for its goods. The high level of export dependence implies that China is strongly coupled rather than 
decoupled with the global economies, while on the financial side its restrictions have kept the strength of its coupling substantially weaker, although well above zero.

Given its high level of export dependence, the surprising fact about the performance of the Chinese economy during the global recession was not that growth slowed substantially but that it was able to remain so high. The reasons behind China's relatively high growth rate in global financial crisis are of interest to researchers and policy makers who are searching for strategies for reducing the damages of future financial crisis.

\section{How Did China Maintain a High Growth Rate during the Crisis?}

5.1. Strong Fiscal Position. In our judgment the key factor of China's high growth rate was its ability to quickly adopt a strong stimulus package. This in turn was feasible because of China's strong financial position.

In the Asian crisis of 1997-98, the crisis hit countries generally had weak financial sectors and low level of international reserves which sharply limited their ability to adopt stimulus policies in the fare of their recessions. These countries learned a great deal from the crisis and substantially strengthened their financial systems and built up high levels of international reserves. Combined with sound fiscal positions, this gave many Asian economies considerable monetary and fiscal space to adopt substantial stimulus packages to help offset much of the decline in their exports. China is a prime example of this phenomenon.

Let us review China's strong financial position in more detail. Because of its solid position, China could afford to generate substantial fiscal and credit expansion. Over the past decade, China's budget deficits as percentage of GDP have been very small, staying less than 3 percent since 2000. In 2007, China even had a budget surplus. Even in the face of the massive stimulus package launched after the onset of the financial crisis, the 2008 and 2009 deficit to GDP ratios were still just 0.4 and 2.2 percent respectively, far smaller than most advanced countries (Figure 2).

When the crisis hit, the Chinese government took rapid countermeasures to mitigate the impact of the global financial crisis. Starting in the third quarter of 2008, the Chinese authorities adopted a combination of an active fiscal policy and a loose monetary policy by introducing an RMB 4 trillion ( $\$ 580$ billion) stimulus package for 2009 and 2010 in November 2008. Those efforts to support the economy during the global financial crisis prompted a surge in bank lending. Bank lending in China totaled RMB 9.6 trillion in 2009 , reaching nearly half of that year's GDP. Substantial funds from bank lending was funneled into the nation's stock and property markets rather than real economic activities, however, which contributed to the partial recovery of China's stock markets from the lows reached in early 2009 [12]. Even after adopting the expansionary fiscal policy, China's debtto-GDP ratio was still lower than 20 percent at the end of 2009. In 2010, the Chinese central government budget deficit remained only 1.7 percent of GDP, as compared with 8.9

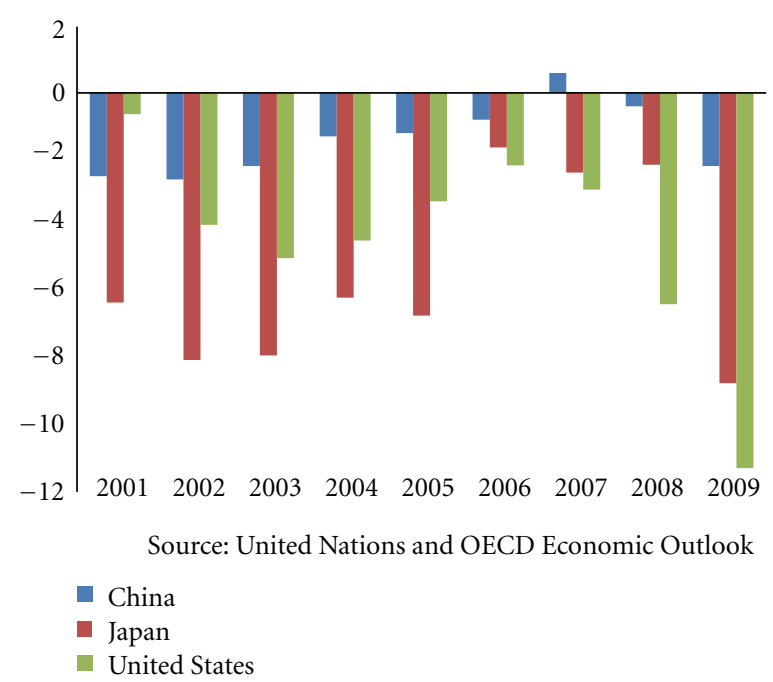

FIGURE 2: Government fiscal balance as percentage of GDP.

percent in the United States. These expansive policies had a major impact on the extent of the drop in growth.

5.2. A High Level of Foreign Exchange Reserves. In emerging market economies, highly expansionary monetary and fiscal policies frequently generate large balance of payments deficits which undermine confidence in their exchange rates and drain international reserves with low levels, so the feasibility of large stimulus policies can be highly constrained. High reserve levels on the other hand make substantial stimulus packages much more feasible. From this perspective China was in an incredibly strong position.

As of the first quarter of 2011, China held foreign exchange reserves of about $\$ 3$ trillion, the highest level in the world and three times that of the next largest holder, Japan. As suggested by Aizenman and Marion [13], international reserves and external borrowing are alternative ways of financing government spending in the face of sovereign risk. China could take advantage of its strong reserve position to adopt a large stimulates package without having to worry about high borrowing costs to fund its government spending, or generating a balance of payment crisis.

5.3. Limited International Capital Flow. Since WTO entry in 2001, China's controls over foreign banks and international capital flows have been reduced. While China has been gradually loosening its control on international financial flows, the regime is still quite restrictive. Despite much discussion of the various ways of evading these controls, they still have enough effectiveness to strongly limit international financial flows. While most economists argue that such controls carry efficiency costs, they can limit a country's exposure to international financial instability.

Most financing for development in China continues to be from domestic sources [14]. For example, the total assets of foreign-funded banks in mainland China was around \$193 billion at the end of March 2008, accounting for only roughly 
2.4 percent of total bank assets in China [15]. Thus, foreignfunded banks remain too small to play an influential role in the financial system [16].

In addition, China has only slowly pursued liberalization of its domestic financial sector, and there has not been a great deal of financial innovations such as Mortgage-Backed Securities (MBS) and Collateralized Debt Obligations (CDO). Between 2007 and 2009, the total losses in China's financial system were limited to just over $2 \%$ of China's precrisis GDP [14].

\section{China's Major Challenges}

While China's success has been remarkable, its economy still faces a number of major challenges.

6.1. Rebalancing the Economy. Despite the enormous success, China's export led growth is not a viable long-run strategy. There is a great deal of consensus including within the Chinese government that a substantial rebalance of the economy is needed. Domestic consumption remains an extremely low proportion of the economy, while dependence on exports is too high. In 2007, for example, earnings from exports accounted for $37 \%$ of China's GDP.

Likewise, serious questions have been raised about the efficiency of the extremely high levels of investment. Such rebalancing will not only provide a more sustainable domestic growth strategy but will also help with reducing global economic imbalances and reduce the treat that importing countries will take protectionist measures against China's exports.

While there is broad agreement on the objectives of rebalancing, progress has been low and faces considerable obstacles. Reducing overinvestment may face substantial political opposition from those who have been gaining from their investment. Increasing domestic consumption relative to saving is also difficult since it will require a substantial expansion of the social safety net in order to reduce the incentive for precautionary savings.

While most economists believe that substantial appreciation of the RMB would help rebalancing as well as reducing inflationary pressures, the short-run dislocations that this would cause also generates political opposition [17].

6.2. Inflationary Pressures and Price Bubbles in the Real Estate Sector. While the Chinese stimulus program was quite successful in reducing the size of the slowdown in economic growth, it carried adverse side effects in terms of increasing inflation and contributing to what many see as a real estate bubble.

While the aim of the stimulus program was to increase consumption and business investment, a substantial proportion of the resulting credit expansion flowed into the stock and real estate markets. Inflation quickly became one of the major challenges in China. Especially sharp price bubbles appeared in the real estate sector. For example, by unofficial estimates, the average price of an apartment in Beijing has risen between five to ten times in the past decade. Thus, China is at risk of a bursting asset price bubble, which would damage its banking sector and credit system even more severely than the 2008-2009 crash [18].

The increases in the general price indices also started to rise soon after the stimulus package was implemented, thus showing signs of a short-run Philips curve where rapid expansions of aggregate demand tend to increase both economic growth and inflation. Since mid-2009, the CPI in China has been increasing overall, reaching around 5.5\% in October 2011 which is higher than the average inflation rate of $4.25 \%$ from 1994 until 2010. These inflationary concerns in turn stimulated the most recent tightening of monetary policy.

6.3. Nonperforming Bank Loans. Nonperforming bank loans have been a problem for some time, and the rapid expansion of credit during the stimulus program has brought this problem to the fore again.

With China central government debt being so low (about $20 \%$ of GDP) and foreign reserves so high, the government has been able to afford to bail out banks. China has recapitalized banks several times after periods of economic stress and to prepare them for WTO entry and eventual foreign competition. In 1998, China issued $\$ 33$ billion worth of special government bonds to recapitalize the four major state-owned banks (Agricultural Bank of China, Bank of China, China Construction Bank, and the Industrial and Commercial Bank of China) which were otherwise technically insolvent. In 1999, China created four asset management companies that bought $\$ 170$ billion of bad loans from these four biggest state-owned banks at face value. Further capital infusions were undertaken in advance of the 2005-2006 initial public offerings (IPOs) of Bank of China, China Construction Bank, and the Industrial and Commercial Bank of China, while a further \$US 19 billion capital injection in November 2008 helped pave the way for Agricultural Bank of China's belated July 2010 IPO [19]. Recently, the government again recapitalized the state-owned banks with an estimated $\$ 56$ billion in 2010. As most of the Chinese banks remain dominated by the government, banks will not refuse to offer new loans if the authorities demand that they do so, even as old loans sour. New lending by banks was equivalent to $31 \%$ and $21 \%$ of GDP in 2009 and 2010, respectively, and 39\% and $34 \%$ of GDP if off-balance-sheet lending is factored in. Over just the first eight months of 2011, Chinese banks reported about $\$ 60$ billion in new nonperforming loans. Among 14 large commercial banks, more than half reported an increase in nonperforming loans (NPL) in excess of $10 \%$ since June 2010 [20] and private estimates are usually much higher than official ones.

By March 2011, China's credit-to-GDP ratio had already risen to $166 \%$ as compared to $120 \%$ at the end of 2008 [21]. As Credit Suisse Group AG suggested when it announced that it was cutting Chinese bank's rating in June 2011, China's credit "has risen to alarming levels in the past two years due to massive off-balance-sheet financing, and raised a red flag for future asset quality problems in banks" [22]. 
6.4. Other Problems. Of course, China faces a number of other economic problems as well. While the global crisis has clearly illustrated the importance of having adequate levels of international reserves, China has accumulated far more reserves than are needed for this purpose. These excess reserves are an inefficient use of scared national resources. There reserve holdings are also more heavily concentrated in dollars than is desirable on grounds of portfolio diversification. Dealing with these issues will not be easy as reducing the level of reserves would require substantial adjustments in the balance of payments and rapid reserve diversification would run the risk of generating a dollar crisis.

Other concerns are how to combine continued rapid economic growth while taking actions to deal with a wide range of environmental issues. Similarly ways must be found to continue to promote growth without continuing large increases in income inequality among both individuals and regions.

How best to continue financial reforms is another difficult issue. The global crisis has painfully illustrated the dangers of inadequate supervision of the financial sector, but the current financial systems in China create a number of serious distortions. Thus, further financial liberalization needs to be pursued, but in a very careful manner.

\section{Concluding Remarks}

A major theme of our paper is that the argument that China's growing economic strength has led to a decoupling from developments in the advanced economies is greatly overstated. China is having an increasingly large impact on the global economy, but economic interdependence runs strongly in both directions.

A second theme has been that, despite its heavy export dependence, China was able to take forceful policy actions to reduce the negative effects of the global recession.

We have also argued that, despite the huge economic strides that China has made, it faces a number of enormous economic challenges to rebalance its economy for sustainable economic growth and playing an increased role in promoting international and regional economic and financial cooperation.

\section{References}

[1] Chinese GDP Share of the World's Total Jumps to 9.5 Pct: NBS, http://news.xinhuanet.com/english2010/china/2011-03/24/c_ 13796714.htm, http://www.Xinhuanet.com/, 2011.

[2] Economist, "Fear of the Dragon-China's Share of World Markets Increased During the Recession," http://www.economist.com/node/15213305, 2010.

[3] MercoPress, "China Takes the Lead Position as the World Main Exporter," http://en.mercopress.com/2010/03/29/chinatakes-the-lead-position-as-the-world-s-main-exporter, 2011.

[4] C. Feenstra Robert and S.-j. Wei, "Introduction to China's Growing Role in World Trade," National Bureau of Economic Research, Working Paper 14716, 2009.

[5] CIA World Fact Book, "China Economy," http://www.photius .com/rankings/economy/imports_2011_0.html, 2011.
[6] L. Linyue, "Deepening Interdependence or Decoupling Hypothesis in East Asia through Trade Transmission: Empirical Studies Using Dynamic Factor Models and Standard Approaches," Dissertation, Claremont Graduate University, 2011.

[7] R. O'Connell, "Chinese Tightening-How will it Affect Precious Metal Demand?" http://www.mineweb.com/mineweb/ view $/ \mathrm{mineweb} / \mathrm{en} /$ page 35 ? oid $=120263 \&$ sn $=$ Detail $\&$ pid $=35$, 2011.

[8] Th. D. Willett, P. Liang, and N. Zhang, "The slow spread of the global crisis," Journal of International Commerce, Economics and Policy, vol. 1, no. 1, pp. 33-58, 2010.

[9] Th. D. Willett, P. Liang, and N. Zhang, "Global contagion and the decoupling debate," in The Evolving Role of Asia in Global Finance (Frontiers of Economics and Globalization, Volume 9), Y.-W. Cheung, V. Kakkar, and G. Ma, Eds., pp. 215-234, Emerald Group Publishing, Bingley, West Yorkshire, 2011.

[10] D. Schmidt, "The Financial Crisis and Its Impact on China," China Analysis Research Group on the Political Economy of China, Trier University, 2009.

[11] Euromonitor, "Can China's Exports of Appliances Grow Any Bigger?” Euromonitor Global Market Research Blog, http:// blog.euromonitor.com/2011/07/can-chinas-exports-of-appliances-grow-any-bigger.html, 2011.

[12] R. C. K. Burdekin and R. Tao, "Bank Lending, Inflation, and China's Stock Market (2004-2010),” This issue, 2012.

[13] J. Aizenman and N. Marion, "International reserve holdings with sovereign risk and costly tax collection," Economic Journal, vol. 114, no. 497, pp. 569-591, 2004.

[14] ActionAid, "Where Does it Hurt? The Impact of the Financial Crisis on Developing Countries," http://www.actionaid .org.uk/doc_lib/where_does_it_hurt_final.pdf, 2009.

[15] China Daily, "Foreign-Funded Banks in China Own \$193b in Assets," http://www.chinadaily.com.cn/business/2008-07/07/ content_6824342.htm, 2008.

[16] W. Xiaoyi, "China's exchange rate and monetary policies," Tech. Rep. 57, BIS, 2010.

[17] Th. D. Willett, P. Liang, and A. Ouyang, "The RMB debate and international influences on China's money and financial markets," in China's Emerging Financial Markets: Challenges and Opportunities, J. R. Barth, J. A. Tatom, and G. Yago, Eds., vol. 8 of The Milken Institute Series on Financial Innovation and Economic Growth, pp. 267-301, Springer, New York, NY, USA, 2009.

[18] Z. Chen, "A massive deflationary shock to the world," in $A$ Symposium of Views: If the Chinese Bubble Bursts, International Economy, 2010.

[19] R. C. K. Burdekin and R. Tao, "An ABC guide to provincial lending patterns in China: progress and prospects," Chinese Economy, vol. 44, no. 5, pp. 34-54, 2011.

[20] Business Insider, "China's Non-Performing Loan Problem Is Getting Bigger," http://articles.businessinsider.com/2011-0831/ markets/30042983_1_chinese-banks-commercial-bank-reserveratio, 2011.

[21] Market Watch, "Credit Suisse Downgrades China Banks, GDP Cites Inflation, Slowing Growth, and Continued Tightening," http://www.marketwatch.com/story/credit-suisse-downgrades-china-banks-gdp-2011-06-20, 2011.

[22] Caijing, "China Banks' Non-Performing Loans may Hit 15Pct: Fitch Ratings, June," http://english.caijing.com.cn/2011-0622/110753514.html, 2011. 


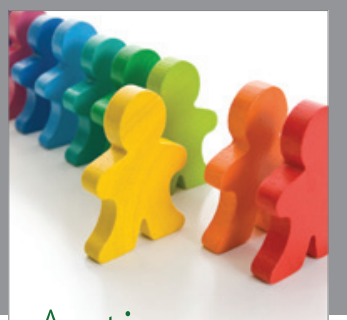

Autism

Research and Treatment
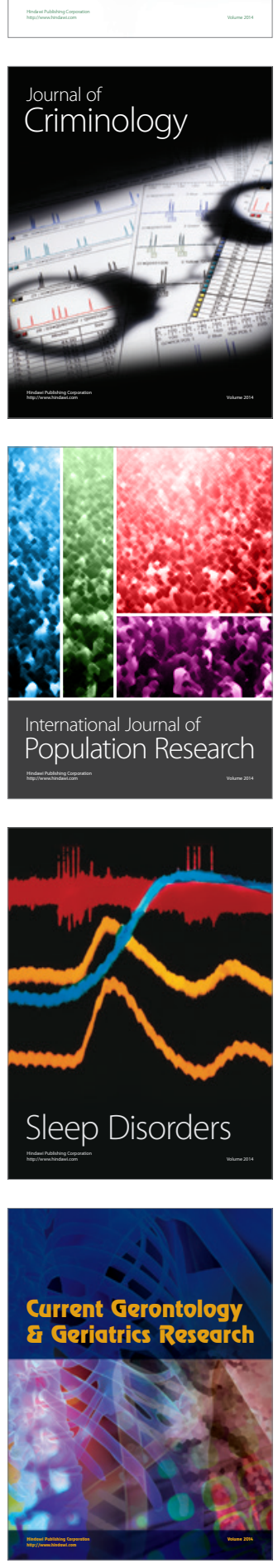
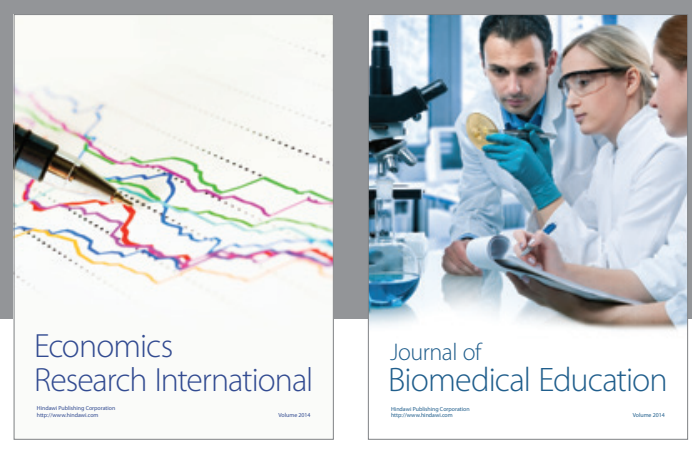

Journal of

Biomedical Education

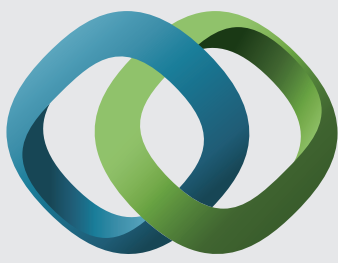

\section{Hindawi}

Submit your manuscripts at

http://www.hindawi.com
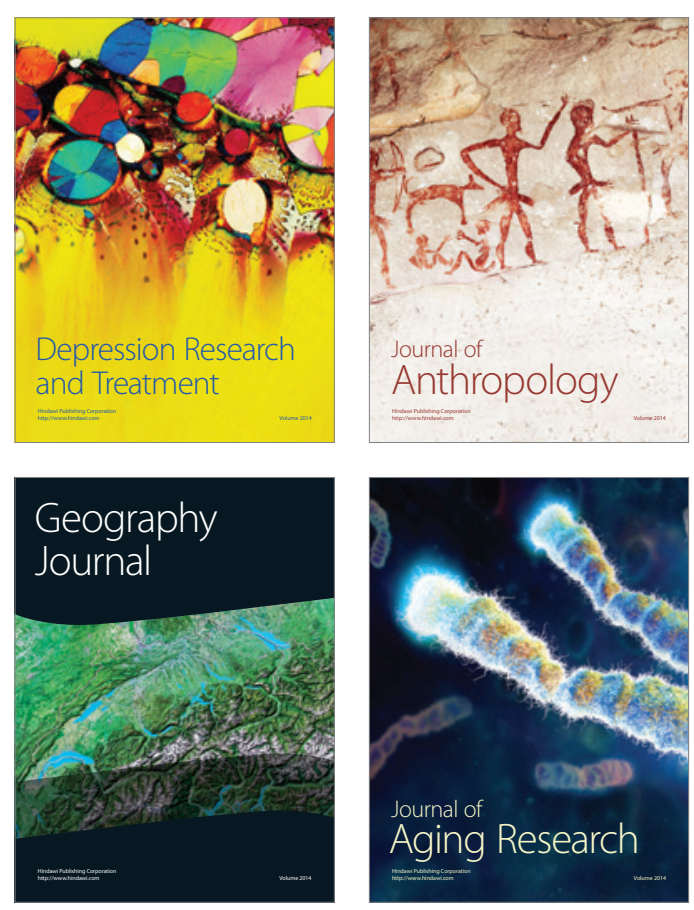

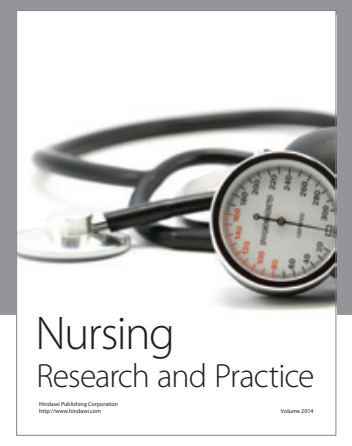

Nursing

Research and Practice

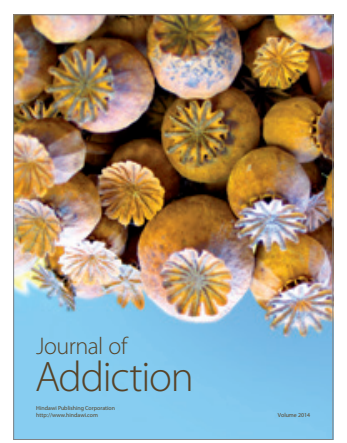

Child Development

Research

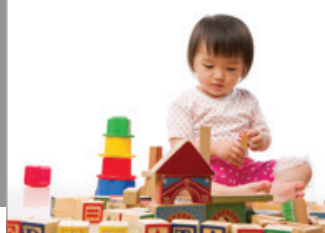

迥
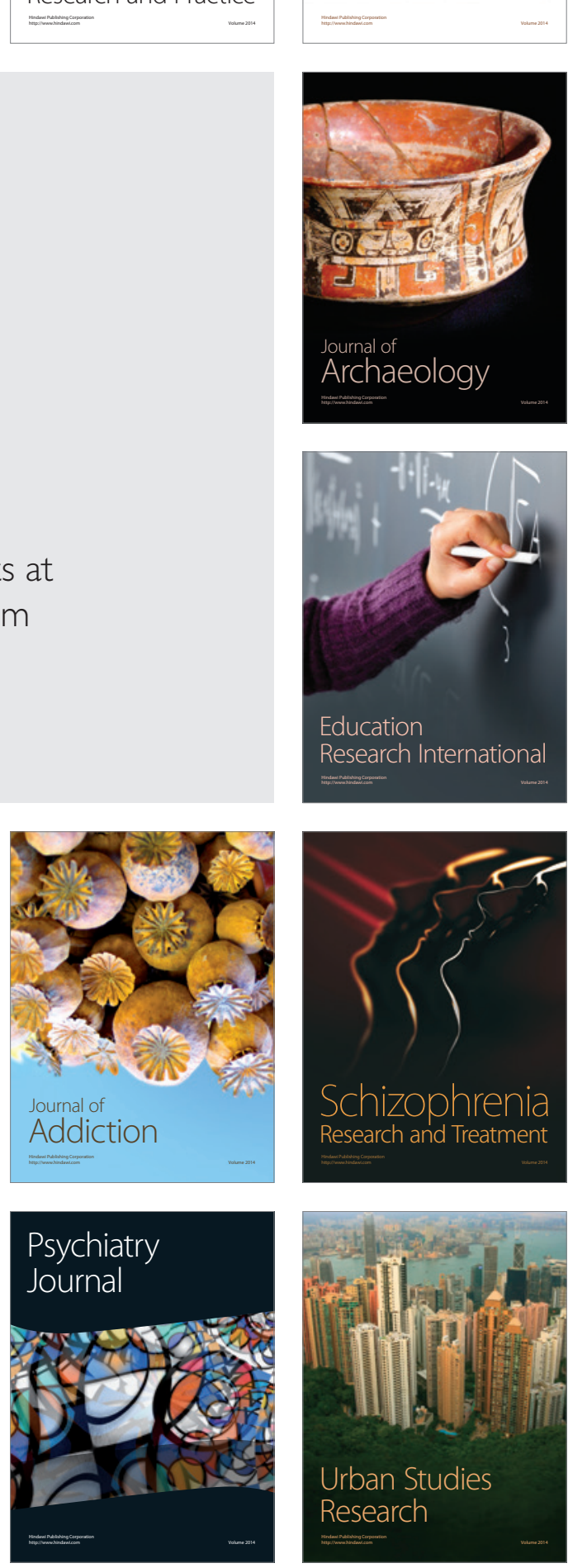